\title{
Chlorophyll $a$ Fluorescence: a Fast and Low-Cost Tool to Detect Superficial Scald in 'Rocha' Pear (Pyrus communis L. 'Rocha')?
}

\author{
I. Gardé ${ }^{1}$, M.D. Antunes ${ }^{2}$, J. Marques da Silva ${ }^{3}$, R. Guerra ${ }^{4}$ and A.M. Cavaco ${ }^{4}$ \\ ${ }^{1}$ UALG, Ed. 8 FCT, Campus de Gambelas, 8005-139 Faro, Portugal \\ 2 IBB-CBV, Ed. 8 FCT, UALG, Campus de Gambelas, 8005-139 Faro, Portugal \\ ${ }^{3}$ BioFIG, FCUL, UALG, Campo Grande, 1749-016 Lisboa, Portugal \\ ${ }^{4}$ CEOT, UALG, Ed. 2 FCT, Campus de Gambelas, 8005-139 Faro, Portugal
}

Keywords: diagnosis, fruit photosynthesis, photosynthetic pigments, disorder

\begin{abstract}
This study aimed to test whether the chlorophyll $a$ (Chla) fluorescence determined by a low-cost non-modulated fluorometer could provide fast, reliable and non-invasive estimators of superficial scald in 'Rocha' pear (Pyrus communis $L$. 'Rocha'). Fruit were harvested before the optimal maturation stage and cold stored under normal atmosphere for 7 months $\left(\mathrm{NA}: 0^{\circ} \mathrm{C}, 90-95 \% \mathrm{RH}\right)$ and 2 in controlled atmosphere $\left(\mathrm{CA}: 0^{\circ} \mathrm{C}, 90-95 \% \mathrm{RH}, 1.5 \mathrm{kPaO}_{2}+0.5 \mathrm{kPa} \mathrm{CO}_{2}\right)(\mathrm{T})$, or harvested at the optimal maturation stage and cold stored for 9 months under $C A(C)$. Then, they were transferred to shelf-life conditions $\left(22 \pm 2^{\circ} \mathrm{C}, 70 \% \mathrm{RH}\right)$ and followed for $7 \mathrm{~d}$. Chla fluorescence, scald index (SI), ripening attributes, $\alpha$-farnesene, conjugated trienols, and photosynthetic pigments were determined for each pear in both groups. Conditions chosen before shelf-life did not prevent the subsequent ripening of any fruit, but changed dramatically the superficial scald development pattern: in $\mathbf{C}$ fruit, the disorder developed progressively during shelf-life, whereas in $\mathrm{T}$ fruit, it peaked during storage. $C$ fruit exhibited a significant negative correlation $(R=-0.65 ; p<0.05)$ between $\mathrm{Fv} / \mathrm{Fm}$ and scald development, but not with ripening $(R=-0.15 ; p<0.05)$. As expected, the opposite was observed in $T$ fruit, in which only a low, positive, yet significant correlation was found between $\mathrm{Fv} / \mathrm{Fm}$ and ripening $(\mathrm{R}=0.44 ; p<0.05)$. The multiple regression approach using $\mathrm{Fv} / \mathrm{Fm}$ and other $\mathrm{Chl} a$ fluorescence parameters produced an equation from which we calculated the 'predicted' scald index in C fruit. This correlated clearly $(R=0.73 ; p<0.05)$ with the real values visually assessed. If color values $a^{*}, b^{*}$ and ${ }^{\circ}$ Hue were included in this multiple regression, the correlation was significantly enhanced $(0.91 ; p<0.05)$. Although preliminary, this study has shown that basic Chla fluorescence parameters are valuable estimators of superficial scald in 'Rocha' pear and might be used in the early detection of the disorder.
\end{abstract}

\section{INTRODUCTION}

'Rocha' pear (Pyrus communis L. 'Rocha'), is a Portuguese exclusive and valuable POD pear cultivar, unfortunately, very prone to superficial scald. This is a physiological disorder promoted by the long-term cold-storage used to extend postharvest life and maintain fruit quality. Scalded 'Rocha' exhibits brown patches on the peel and becomes unsuitable for the market as a fresh commodity. While stored, it requires continuous manual labor to sort out and eliminate the pears affected by the disorder, due to its enhanced sensitivity to biological spoilage. In fact, superficial scald remains a worldwide pressing and economical issue, demanding for strict preventive methods, which have mainly included the use of critical chemicals for human health, such as diphenylamine (DPA) (e.g., Isidoro and Almeida, 2006). However, DPA has been prohibited in the EU market from March 2011 onwards. Both physical and chemical alternatives extensively tested in several pome fruit, including 'Rocha' pear (fruit heating before cold-storage, 1MCP, essential oils, etc.) as well as the biochemical evaluation of some antioxidants pattern during long-term storage have not yet provided a final solution for this worldwide issue (e.g., Silva et al., 2010).

Independently of the ultimate solution that researchers might provide to avoid superficial scald, one should consider the parallel development of some sort of a fast, 
non-invasive and keen method to be used in the online sorting systems, which could predict the probability of the disorder when fruit enter the storing and packing warehouses facilities. This would provide in the long-term the most sustainable approach to the postharvest management of fruit quality by predicting scald prevalence before any visual damage occurs, which fruit has potential for long-term storage and the corresponding conditions, and which fruit should be commercialised in the short-term.

Chl $a$ fluorescence technique is a fast, non-invasive and reliable tool used to assess photosynthesis response to stress in both plants and fruit (Saquet and Streif, 2002; Cavaco et al., 2003). Chl $a$ fluorescence parameters (e.g., Fv/Fm) are reliable and accurate estimators of early changes in the chloroplastic structure/function before any tissue visual damage occurs. They have been used also for predicting of ripening and quality of fruit (for a review see Dell and Toivonen, 2003). Indeed, pome fruit presents a specific but highly efficient photosynthetic metabolism on the respective peel tissue (Blanke and Lenz, 1989), which happens in dimorphic chloroplasts containing on their thylakoids the light harvesting chlorophyll protein (LHC) complexes and the two photosystems $\left(\mathrm{PS}_{\mathrm{I}}\right.$ and $\mathrm{PS}_{\mathrm{II}}$. Both thylakoids and $\mathrm{PS}_{\mathrm{II}}$ are highly sensitive to a wide variety of stresses, leading to oxidative conditions, and usually respond through changes in the antenna chlorophyll $a$ (Chl a) emitted fluorescence (Schreiber et al., 1994). Superficial scald involves the synthesis of strong oxidants (CTos) that trigger a non-stop process of oxidation on the fruit peel ultrastructure, through the presence of several reactive oxygen species (ROS). This leads to membranes lipid peroxidation, the resulting development of the typical brown patches on the fruit peel and most probably to Chl $a$ fluorescence changes.

Indeed, several Chl $a$ fluorescence parameters have already been tested as superficial scald indicators, although with a limited success, due to the biased results caused by ripening (see the review by Dell and Toivonen, 2003). In contrast a decreasing Fv/Fm has already been used successfully to predict the internal browning in 'Conference' pear, before it is expressed (Saquet and Streif, 2002). As far as we know, Chl $a$ fluorescence has already been evaluated to provide ripening indicators for 'Rocha' pear with a reasonable success (Elias et al., 2004 a,b; Ramalho et al., 2007). Additionally, there is a large offer of inexpensive, portable fluorometers that allow for the computerized data handling, and therefore simple data manipulation, analysis and summary.

This study aimed to test whether the chlorophyll $a$ (Chl $a)$ fluorescence determined by a low-cost, non-modulated fluorometer could provide fast, reliable and non-invasive estimators of superficial scald in 'Rocha' pear (Pyrus communis L. 'Rocha').

\section{MATERIALS AND METHODS}

\section{Fruit and Storage Conditions}

'Rocha' pear (Pyrus communis L. 'Rocha') fruit was harvested randomly from several orchards of the same producer located in Mafra (Portugal) and transported immediately after harvest to a storage warehouse (Frutoeste, Mafra, Portugal) and handsorted to select undamaged fruit. Although none of the fruit groups were treated physically or chemically against superficial scald, it is known that controlled atmospheres may prevent significantly the disorder (e.g., Isidoro and Almeida, 2006). Fruit were harvested before the optimal maturation stage (size 35-50) and cold stored under normal atmosphere for 7 months (NA: $0{ }^{\circ} \mathrm{C}, 90-95 \% \mathrm{RH}$ ) and 2 in controlled atmosphere (CA: $\left.0^{\circ} \mathrm{C}, 90-95 \% \mathrm{RH}, 1.5 \mathrm{kPaO}_{2}+0.5 \mathrm{kPa} \mathrm{CO}_{2}\right)(\mathrm{T})$, or harvested at the optimal maturation stage (size 55-70) and cold stored for 9 months under CA (C). Afterwards, they were transferred to shelf-life $\left(22 \pm 2^{\circ} \mathrm{C}, 70 \% \mathrm{RH}\right)$ at the University of Algarve (Faro, Portugal) and followed for $7 \mathrm{~d}$. The first measurements $(0 \mathrm{~d})$ started after the fruit were equilibrated overnight at the shelf-life conditions, and sampling occurred 3 times during this period $(0$, 2 , and $7 \mathrm{~d}$ ). Unless stated otherwise, measurements were carried out on four opposite positions on the equator of each pear, each result representing the average of the four values. All peel discs and segments, as well as pulp samples, were collected immediately 
after the determination of the non-invasive and ripening attributes in each fruit, frozen in liquid $\mathrm{N}_{2}$ and stored at $-80^{\circ} \mathrm{C}$ until the respective assay.

\section{Assessment of Superficial Scald}

Fruits were visually assessed for scald and sorted according to the respective scald index (SI), which stands for the sum of all scald patches surface area per fruit $(0: 0 \%$; $1:>0 \leq 5 \% ; 2: 5-10 \% ; 3: 10-25 \% ; 4: 25-50 \% ; 5:>50 \%)$.

\section{Chlorophyll $a$ Fluorescence}

Dark-adapted chlorophyll $a$ fluorescence $(\mathrm{Chl} a)$ parameters of fruit peel, were determined non-invasively, always at the same time of the day, after a pre-adaptation to dark for at least $1 \mathrm{~h}$, with a low-cost, non-modulated fluorometer (OS-30p, Chlorophyll Fluorometer, Opti-Sciences Inc., Hudson, North America) at $23 \pm 2{ }^{\circ} \mathrm{C}$. Minimal fluorescence $\left(\mathrm{F}_{0}\right)$, maximal fluorescence $\left(\mathrm{F}_{\mathrm{m}}\right)$, and the maximum quantum yield of photosystem II $\left(\mathrm{PS}_{\mathrm{II}}\right)\left[\mathrm{F}_{\mathrm{v}} / \mathrm{F}_{\mathrm{m}}=\left(\mathrm{F}_{\mathrm{m}}-\mathrm{F}_{0}\right) / \mathrm{F}_{\mathrm{m}}\right]$ (Dell and Toivonen, 2003 and references therein) were determined directly by the fluorescence device. To determine $F_{m}$, a saturating pulse of $1 \mathrm{~s}$ and PPFD $3000 \mu \mathrm{mol} \mathrm{m} \mathrm{m}^{-2} \mathrm{~s}^{-1}$ was used. Other fluorescence parameters and/or ratios were further derived from Roháček and Barták (1999).

\section{Fruit Ripening}

Fruit surface colour was determined at three different positions along each of the fruit quarters, in a non-destructive manner with a colorimeter (Minolta CR-200 Chroma meter, Japan) in the CIE L*a*b* colour space. Firmness was determined by puncture, after peel removal, with a penetrometer Chatillon force gauge (TCD200, Digital Force Gauge Dfis50, Chatillon, USA) fitted with an $8 \mathrm{~mm}$ diameter plunger to a depth of $7 \mathrm{~mm}$. Soluble solids content (SSC reported as ${ }^{\circ}$ Brix) were determined on fruit juice from the same spots used to determine firmness with a digital refractometer (Atago PR-32, Tokyo, Japan).

\section{$\alpha$-Farnesene and Conjugated Trienols (CTos) Content and Estimation of Total Antioxidants}

$\alpha$-Farnesene and conjugated trienols (CTos) and total antioxidants of 'Rocha' pear frozen discs (1-2) were extracted in $5 \mathrm{ml}$ hexane (HPLC grade) for $10 \mathrm{~min}$, under constant agitation at $23 \pm 2^{\circ} \mathrm{C}$ (Anet, 1972; Isidoro and Almeida, 2006). Extracts were assayed spectrophotometrically at $232 \mathrm{~nm}$ and at 281-290 nm (Shimadzu, UV-Visible recording spectrophotometer, model UV-160A, Shimadzu Corporation, Kyoto, Japan) and content calculated according to the following extinction coefficients, namely, $\varepsilon_{232} \mathrm{~nm}=27740$ for $\alpha$-farnesene and $\varepsilon_{281-290 \mathrm{~nm}}=25000$ for CTos in $\mu \mathrm{g} \mathrm{g} \mathrm{g}^{-1}$ peel $\mathrm{Fw}$. An estimate of total antioxidant content was determined at $200 \mathrm{~nm}\left(\mathrm{OD}_{200}\right)$.

\section{Extraction and Assay of Photosynthetic Pigments}

Two skin discs $\left(\sim 4.5 \mathrm{~cm}^{2}\right)$, immediately frozen in liquid nitrogen after pear fruit peeling, were ground in a pre-chilled mortar containing quartz sand $(\sim 1 \% \mathrm{w} / \mathrm{w})$ and extracted for photosynthetic pigments with ice-cold 80\% acetone $(3 \mathrm{ml})$. Extracts remained on ice and in the dark until they were centrifuged at $4^{\circ} \mathrm{C}$ for $10 \mathrm{~min}$ at $5000 \mathrm{~g}$. The supernatants were assayed spectrophotometrically (Shimadzu, model UV-160A, Shimadzu Corp., Japan) and the concentrations of chlorophyll $a(\mathrm{Chl} a)$, chlorophyll $b$ $(\mathrm{Chl} b)$, total chlorophyll (Chl $a+b)$ and total carotenoids (Car) calculated according to Lichtenthaler (1987). To minimize degradation and isomerisation of chlorophylls, all work was performed in dim light.

\section{Data Analysis}

The effects of time and storage conditions on each of the scald, ripening and quality parameters were tested by a two-way ANOVA and further multiple comparisons among groups were performed by the Student-Newman-Keuls test for a significance level 
of $\mathrm{P}<0.05$ (SPSS v. 13, USA). Pearson's correlations $(\mathrm{P}<0.05)$ were calculated with the SPSS v. 13 (USA), while multiple regressions were determined with Matlab ${ }^{\mathbb{B}}$ 7.9.0 (The Mathworks Inc., USA).

\section{RESULTS AND DISCUSSION}

Conditions chosen before shelf-life did not prevent the subsequent ripening of any fruit, although its time course was slightly different between the two fruit groups (Table 1). Softening is the main attribute that defines 'Rocha' pear ripening stage, and it was used in the data analysis when referring to ripening (e.g., Cavaco et al., 2009). In contrast, storage conditions affected dramatically the superficial scald development: in C fruit, the disorder developed progressively during shelf-life, whereas in T fruit, it peaked (SI 5) during storage (Fig. 1). C fruit behaved as expected based on the previous knowledge that the onset and intensification of superficial scald seems to correlate with the temperature dependence of Ctos auto-oxidation, increasing as temperature rises (Whitaker and Saftner, 2000). Similar results were obtained in 'Rocha' pear and 'Granny Smith' apple (Erkan and Pekmzci, 2004; Isidoro and Almeida, 2006).

The scald index (SI) of 'Rocha' used in this study was not dependent on the precursor-product relationship of $\alpha$-farnesene and conjugated trienols (CTos) per se, as previously observed in both apple and pear (Anet, 1972; Whitaker, 2007). This might relate to the apparent post-climacteric stage of fruit used in the study, as indicated by the significant SSC decrease $(\mathrm{p}<0.05)$ during shelf-life (Table 2). On the contrary, SI was shown to be negatively correlated with the estimate of total antioxidants $\left(\mathrm{OD}_{200}\right)$, despite the fruit group considered (Table 2), as previously shown in apple 'Granny Smith' and 'Starking Delicious' (Thomai et al., 1998; Diamantidis et al., 2002). Overall, these data suggests that superficial scald in 'Rocha' pear is more dependent on the balance between the oxidative process initiated by CTos and the scavenging capacity of the tissue, than of each compound per se. Other interesting results observed in the $\mathrm{C}$ fruit, were the negative correlation between SI and Chl $a+b$, and the strong and positive correlation observed between SI and the ratio Chl $b+\operatorname{Carot} / \mathrm{Chl} a$ (Table 2). This suggests a role for the PS antenna pigments, which would affect $\mathrm{Chl} a$ fluorescence parameters, by contributing to excess energy dissipation as heat. This process is associated with mechanisms of ROS scavenging, played by carotenoids under oxidative conditions in the chloroplast, such as those involved in superficial scald development (Fig. 1 and Table 2) (see the review by Merzlyak and Solovchenko, 2002 and Solovchenko et al., 2006).

No fluorescence signal was detected on the scald patches. Thus, fluorescence data were forcedly determined in the nearby areas, suggesting that the disorder progression could and should be followed by this technique before visual damage occurred. $\mathrm{C}$ fruit exhibited a significant negative correlation $(R=-0.65 ; p<0.05)$ between $F v / F m$ and $S I$, but no significant correlation with firmness (Fig. 3A). As expected, the opposite was observed in $\mathrm{T}$ fruit, in which only a low, positive, yet significant correlation was found between Fv/Fm and ripening. Although T pears could not be used in the following correlation and multiple regression analysis due to its maximal and unchanged SI during shelf-life, it turned out quite useful, because it allowed assessment of ripening on the fluorescence changes (Fig. 2B). This is very important, because previous reports on the use of these changes to predict superficial scald in apples provided results biased by the concomitant effect of ripening (Beaudry et al., 1995). However, in this study with 'Rocha' pear, it was clearly shown that when occurring simultaneously, the scald effect on fluorescence was predominant over ripening (Fig. 2).

Furthermore, the multiple regression approach using $\mathrm{Fv} / \mathrm{Fm}$ and other $\mathrm{Chl} a$ fluorescence parameters produced an equation from which we calculated the 'predicted' $\mathrm{SI}$ in $\mathrm{C}$ fruit. This correlated well $(\mathrm{R}=0.73 ; \mathrm{p}<0.05)$ with the real values visually assessed. If color values $a^{*}, b^{*}$ and Hue were included in this multiple regression, the correlation was significantly enhanced $(0.91 ; p<0.05)$. Although preliminary, this study has shown that basic Chl $a$ fluorescence parameters are valuable estimators of superficial scald in 'Rocha' pear and might be used in the early detection of the disorder. 


\section{ACKNOWLEDGEMENTS}

Frutoeste. Project funded by CEOT and the Programa Nacional de Reequipamento Científico (PNRC) by FCT (Fundação para a Ciência e a Tecnologia) (REEQ/601/EEI/2005) and the POCI 2010-FEDER.

\section{Literature Cited}

Anet, E.F.L.J. 1972. Superficial scald, a functional disorder of stored apples. VIII. Volatile products from the autoxidation of a-farnesene. J. Sci. Food. Agric. 23:605-608.

Beaudry, R.M., Song, J. and Deng, W. 1995. Using chloroplast fluorescence for prediction of scald development in 'Red Delicious' apple fruit. HortScience 30:816 (abstract).

Blanke, M.M. and Lenz, F. 1986. Fruit Photosynthesis. Plant, Cell and Envir. 12:31-46.

Cavaco, A.M., Silva, A.B. and Arrabaça, M.C. 2003. Effects of long-term chilling on growth and photosynthesis of the $\mathrm{C}_{4}$ gramineae Paspalum dilatatum. Physiol. Plant. 119:87-96.

Cavaco, A.M., Pinto, P., Antunes, M.D., Marques da Silva, J. and Guerra, R. 2009. 'Rocha' pear firmness predicted by a Vis/NIR segmented model. Postharvest Biol. Technol. 51(3):311-319.

Dell, J.R. and Toivonen, M.A. 2003. Use of Chlorophyll fluorescence in postharvest quality assessment of fruits and vegetables. p.204-242. In: J.R. Dell and M.A. Toivonen (eds.), Practical Applications of Chlorophyll Fluorescence in Plant Biology. Kluwer Academic Publishers, USA.

Diamantidis, G., Thomai, T., Genitsariotis, M., Nanos, G., Bolla, N. and Sfakiotakis, E. 2002. Scald susceptibility and biochemical/physiological changes in respect to low preharvest temperature in 'Starking Delicious' apple fruit. Sci. Hortic. 92:361-366.

Elias, E., Marques da Silva, J., Antunes, R. and Bernardes da Silva, A. 2004a. Modulated chlorophyll fluorescence and post-harvesting control of 'Rocha' pear quality - I. Aspects of fruit photosynthesis. Actas do IV Simpósio Ibérico sobre Maturação e PósColheita (Barreiro M.G. ed.), Oeiras, Portugal, p.51-55.

Elias, E., Marques da Silva, J., Antunes, R. and Bernardes da Silva, A. 2004b. Modulated chlorophyll fluorescence and post-harvesting control of 'Rocha' pear quality - II. Fluorescence as an indicator of maturation. Actas do IV Simpósio Ibérico sobre Maturação e Pós-Colheita (Barreiro M.G. ed.), Oeiras, Portugal, p.179-183.

Erkan, M. and Pekmezci, M. 2004. Harvest date influences superficial scald development in Granny Smith apples during long term storage. Turk. J. Agric. For. 28:397-403.

Isidoro, N. and Almeida, D.P.F. 2006. Alpha-Farnesene, conjugated trienols, and superficial scald in 'Rocha' pear as affected by 1-methylcyclopropene and diphenylamine. Postharvest Biol. Technol. 42(1):49-56.

Lichtenthaler, H.K. 1987. Chlorophylls and carotenoids: pigments of photosynthetic biomembranes. p.351-372. In: Methods in Enzymology, Vol. 148. Academic Press, London.

MATLAB $^{\circledR}$ 5R, The MathWorks, Inc., Natick, MA, USA.

Merzlyak, M.N. and Solovchenko, A.E. 2002. Photostability of pigments in ripening apple fruit: a possible photoprotective role of carotenoids during plant senescence. Plant Sci. 163:881-888.

Ramalho, J.C. 2007. Maturity assessment of Pyrus communis L. cv. Rocha at harvest and along cold storage through chlorophyll $a$ fluorescence and colour parameters. Acta Hort. 800:1053-1060.

Roháček, K. and Barták, M. 1999. Technique of the modulated chlorophyll fluorescence: basic concepts, useful parameters, and some applications. Photosyn. 37(3):339-363.

Saquet, A.A. and Streif, J. 2002. Chlorophyll fluorescence as a predictive method for detection of browning disorders in 'Conference' pears and 'Jonagold' apples during controlled atmosphere storage. Ciência Rural 3:571-576.

Schreiber, U., Bilger, W. and Neubauer, C. 1994. Chorophyll fluorescence as a nonintrusive indicator for rapid assessment of in vivo photosynthesis. p.49-70. In: E.D. Schulze and M.M. Caldwell (eds.), Ecophysiology of Photosynthesis. Vol. 100, 
Springer, Berlin.

Silva, F.J.P., Gomes, M.H., Fidalgo, F., Rodrigues, J.A. and Almeida, D.P. 2010. Antioxidant properties and fruit quality during long-term storage of 'Rocha' pear: effects of maturity and storage conditions. J. Food Qual. 33(1):1-20.

Solovchenko, A.E., Avertcheva, O.V. and Merzlyak, M.N. 2006. Elevated sunlight promotes ripening associated pigment changes in apple fruit. Postharvest Biol. Technol. 40:183-189.

Thomai, T., Sfakiotakis, E., Diamantidis, Gr. and Vasilakakis, M. 1998. Effects of low temperature on scald susceptibility and biochemical changes in 'Granny Smith' apple peel. Sci. Hortic. 76:1-15.

Whitaker, B.D. 2007. Oxidation products of alpha-farnesene associated with superficial scald development in d'Anjou pear fruits are conjugated trienols. J. Agric. Food. Chem. 55(9):3708-3712.

Whitaker, B.D. and Saftner, R.A. 2000. Temperature-dependent autoxidation of conjugated trienols from apple peel yields 6-methyl-5-hepten-2-one, a volatile implicated in induction of scald. J. Agric. Food Chem. 48(6):2040-2043.

\section{Tables}

Table 1. Ripening attributes of 'Rocha' pear of $\mathrm{C}$ (mature fruit at harvest; stored for 9 months in $\mathrm{CA}: 0{ }^{\circ} \mathrm{C}, 90-95 \% \mathrm{RH}, 1.5 \mathrm{kPaO}_{2}+0.5 \mathrm{kPa} \mathrm{CO}$ ) and $\mathrm{T}$ (immature fruit stored 7 months in NA: $0^{\circ} \mathrm{C}, 90-95 \% \mathrm{RH}+2$ months in CA) fruit groups after shelflife $\left(22 \pm 2^{\circ} \mathrm{C}\right.$ and $\left.70 \% \mathrm{RH}\right)$. None of the pears $(\mathrm{N}=45)$ were treated preventively against superficial scald before storage. Results in the table are the mean \pm SE of 5-10 fruit.

\begin{tabular}{lcccc}
\hline Shelf-life & \multicolumn{2}{c}{ Firmness (N) } & \multicolumn{2}{c}{ SSC $\left({ }^{\circ}\right.$ Brix $)$} \\
\cline { 2 - 5 }$(\mathrm{d})$ & $\mathrm{C}$ & $\mathrm{T}$ & $\mathrm{C}$ & $\mathrm{T}$ \\
\hline 0 & $23.4 \pm 1.5$ & $35.6 \pm 3.0$ & $13.5 \pm 0.3$ & $12.3 \pm 0.4$ \\
2 & $23.9 \pm 3.2$ & $21.5 \pm 2.2$ & $11.5 \pm 0.2$ & $12.4 \pm 0.6$ \\
7 & $13.0 \pm 2.0$ & $12.4 \pm 1.3$ & $11.1 \pm 0.6$ & $10.2 \pm 0.4$ \\
\hline
\end{tabular}

Table 2. Pearson's correlations between SI and the superficial scald inducing chemical compounds and photosynthetic pigments in the peel of 'Rocha' pear of $\mathrm{C}$ (mature fruit stored 9 months in $\mathrm{CA}: 0^{\circ} \mathrm{C}, 90-95 \% \mathrm{RH}, 1.5 \mathrm{kPaO}_{2}+0.5 \mathrm{kPa} \mathrm{CO}$ ) and $\mathrm{T}$ (immature fruit stored 7 months in NA: $0^{\circ} \mathrm{C}$, HR $90-95 \%+2$ months in $\mathrm{CA}$ ) fruit groups after shelf-life $\left(22 \pm 2^{\circ} \mathrm{C}, 70 \% \mathrm{RH}\right)$. None $(\mathrm{N}=45)$ were treated preventively against superficial scald before storage. Statistically significant correlations at $\mathrm{p}<0.05$ are indicated by *.

\begin{tabular}{lcccccc}
\hline $\begin{array}{l}\text { SI } \\
(0-5)\end{array}$ & $\begin{array}{c}\text { Ctos } \\
\alpha \text {-farn }\end{array}$ & $\mathrm{OD}_{200}$ & $\begin{array}{c}\text { OD200 } \\
\text { CTos }\end{array}$ & $\begin{array}{c}\mathrm{Chl} a+b \\
\left(\mathrm{mg} \mathrm{m}^{-2}\right)\end{array}$ & $\begin{array}{c}\text { Carot } \\
\left(\mathrm{mg} \mathrm{m}^{-2}\right)\end{array}$ & $\begin{array}{c}\text { Chl } b+\text { Carot } \\
\text { Chl } a\end{array}$ \\
\hline C fruit & 0.49 & $-0.81^{*}$ & $-0.59^{*}$ & $-0.67^{*}$ & 0.52 & $0.82^{*}$ \\
T fruit & 0.16 & $-0.42^{*}$ & -0.04 & 0.36 & -0.18 & -0.23 \\
\hline
\end{tabular}




\section{Figures}

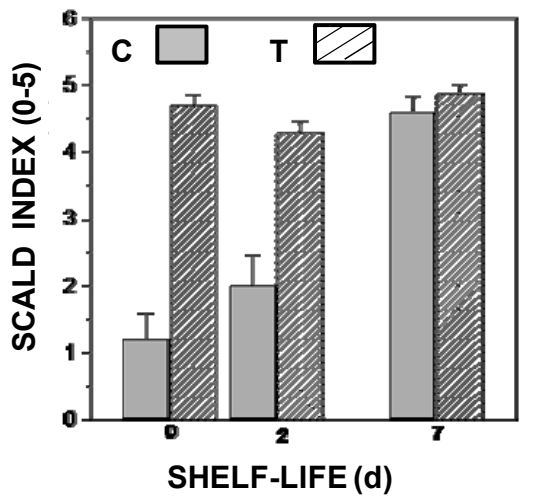

Fig. 1. Scald index (SI) $(0: 0 \% ; 1:>0 \leq 5 \% ; 2: 5-10 \% ; 3: 10-25 \% ; 4: 25-50 \% ; 5:>50 \%)$ in 'Rocha' pear of $\mathrm{C}$ (mature fruit stored 9 months in $\mathrm{CA}: 0^{\circ} \mathrm{C}, 90-95 \% \mathrm{RH}$, $1.5 \mathrm{kPaO}_{2}+0.5 \mathrm{kPa} \mathrm{CO}$ ) and $\mathrm{T}$ (immature fruit stored 7 months in NA: $0^{\circ} \mathrm{C}$, $90-95 \% \mathrm{RH}$ and 2 months in CA) fruit groups after shelf-life $\left(22 \pm 2^{\circ} \mathrm{C}\right.$ and $70 \%$ $\mathrm{RH})$. None of the pears were treated preventively against superficial scald before storage. Columns represent the mean $( \pm \mathrm{SE})$ of 5-10 fruit.

$A: R(C)=0.65 * ; R(T)=-0.15$

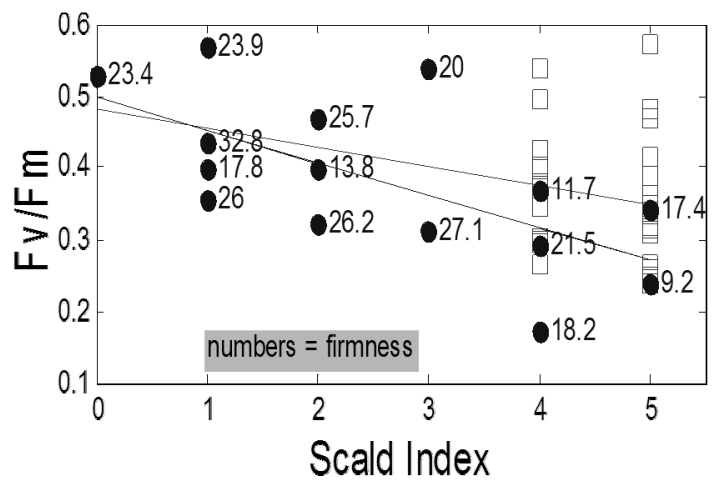

B: $R(C)=0.32 ; R(T)=0.44$ *

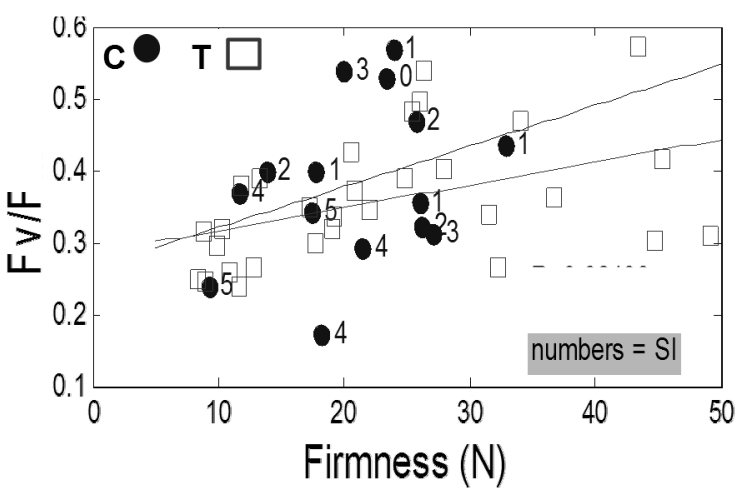

Fig. 2. Pearson's correlation $(\mathrm{p}<0.05)$ between $\mathrm{Fv} / \mathrm{Fm}$ and SI of $\mathrm{C}$ (mature fruit stored 9 months in $\mathrm{CA}: 0^{\circ} \mathrm{C}, 90-95 \% \mathrm{RH}, 1.5 \mathrm{kPaO}_{2}+0.5 \mathrm{kPa} \mathrm{CO}$ ) and $\mathrm{T}$ (immature fruit stored 7 months in NA: $0^{\circ} \mathrm{C}, 90-95 \% \mathrm{RH}$ and 2 months in CA) fruit groups after shelf-life $\left(22 \pm 2^{\circ} \mathrm{C}\right.$ and $\left.70 \% \mathrm{RH}\right)$. None $(\mathrm{N}=45)$ were treated preventively against superficial scald before storage. Statistically significant correlations at $\mathrm{p}<0.05$ are indicated by $*$. 
$A: R(C)=0.73 * ; R(T)=38$

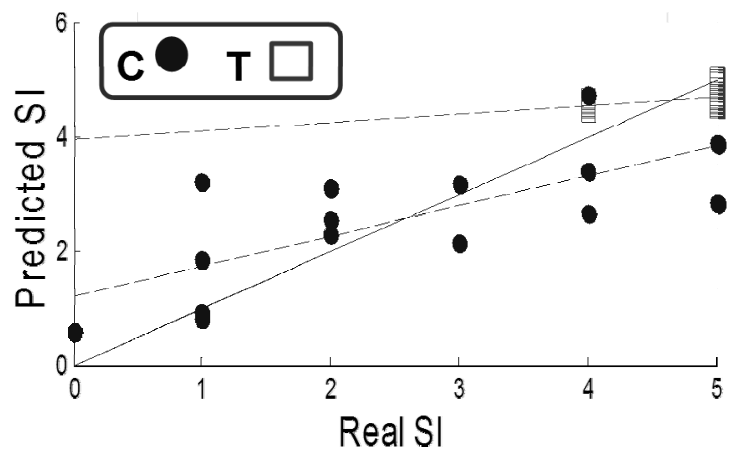

B: $R(C)=0.91 * ; R(T)=0.55$

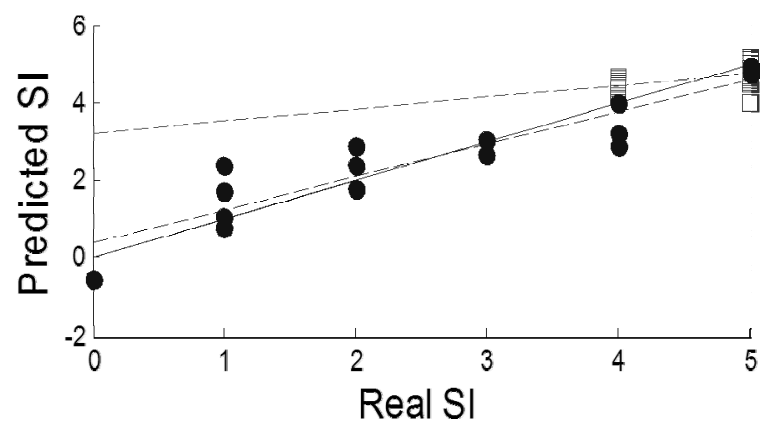

Fig. 3. Pearson's correlation $(\mathrm{p}<0.05)$ between 'predicted' and visually assessed/real SI of $\mathrm{C}$ (mature fruit stored 9 months in $\mathrm{CA}: 0^{\circ} \mathrm{C}, 90-95 \% \mathrm{RH}, 1.5 \mathrm{kPaO}_{2}+0.5 \mathrm{kPa} \mathrm{O}$ ) and $\mathrm{T}$ (immature fruit stored 7 months in NA: $0{ }^{\circ} \mathrm{C}, 90-95 \% \mathrm{RH}$ and 2 months in $\mathrm{CA})$ fruit groups after shelf-life $\left(22 \pm 2^{\circ} \mathrm{C}\right.$ and $\left.70 \% \mathrm{RH}\right)$. None of the pears $(\mathrm{N}=45)$ were treated preventively against superficial scald before storage. Multiple regressions approach using SI and $\mathrm{Chl} a$ fluorescence parameters (A), SI and Chl $a$ fluorescence + color parameters (B), were determined with Matlab ${ }^{\circledR}$ 7.9.0 (The Mathworks Inc., USA). The resulting equations were used to calculate the 'predicted' scald index (SI). Statistically significant correlations at $\mathrm{p}<0.05$ are indicated by *. 